\title{
Comparison of epizootic haematopoietic necrosis and Bohle iridoviruses, recently isolated Australian iridoviruses
}

\author{
Sandra G. Hengstberger ${ }^{1}$, Alex D. Hyatt ${ }^{1, *}$, Rick Speare ${ }^{2}$, Barbara E. H. Coupar ${ }^{1}$ \\ ${ }^{1}$ Australian Animal Health Laboratories, C.S.I.R.O., PO Bag 24, Geelong 3220, Victoria, Australia \\ ${ }^{2}$ Anton Breinl Centre for Tropical Health and Medicine, James Cook University of North Queensland, Townsville 4811, \\ Queensland, Australia
}

\begin{abstract}
Epizootic haematopoietic necrosis virus (EHNV) and Bohle virus (BIV) are piscine and amphibian iridoviruses respectively which have been isolated in Australia from redfin perch Perca fluviatilis L., cultured rainbow trout Oncorhynchus mykiss (Walbaum) and the ornate burrowing frog Limnodynastes ornatus (Gray). To determine whether the viruses were similar they were examined at the ultrastructural, protein, antigenic and genomic levels. EHNV was found to differ from BIV in cytopathic effect on host cells, size, site of virus release, molecular weights of proteins and restriction endonuclease digest profiles of the respective DNA's. On the other hand both iridoviruses were also found to infect a similar range of tissue culture cells, exhibit a similar sequence of ultrastuctural events and possess proteins of similar antigenic reactivity. DNA from EHNV and BIV cross hybridized to a high level. When the BIV polypeptides were compared to the published data for purified frog virus 3 (FV3) and with the appropriate restriction enzyme profiles, a similarity was noted between the 2 viruses. This implies that EHNV, which shares many structural and biochemical characteristics with BIV, is itself related to the Ranavirus genus of iridoviruses.
\end{abstract}

\section{INTRODUCTION}

Epizootic haematopoietic necrosis virus (EHNV), a piscine iridovirus (Eaton et al. 1991), has been isolated from redfin perch Perca fluviatilis L. and cultured rainbow trout Oncorhynchus mykiss (Walbaum) in Victoria, Australia (Langdon et al. 1986, 1988). Outbreaks reported since 1984 have involved mass mortalities of fish populations within Victoria, New South Wales and South Australia. EHNV is also known to cause disease in a range of fish species (Langdon 1989) and may be implicated in the population decline of at least 1 indigenous species, namely Macquarie perch Macquaria australasia (Curvier) (Langdon 1989). The presence of the virus in Australian rainbow trout hatcheries has resulted in the enforcement of restrictions in the sale and movement of fish from these hatcheries.

- Addressee for correspondence
The family Iridoviridae encompasses 4 named genera including Iridovirus (represented by type 1 Tipula iridescent virus), Chloriridovirus (e.g. type 2 mosquito iridescent virus), Ranavirus (e.g. frog virus 3, FV3), Lymphocystivirus (e.g. fish lymphocystis disease virus, FLDV) and a fifth proposed 'goldfish group' (Francki et al. 1991). The piscine iridoviruses include FLDV and goldfish virus (GFV). These 2 groups are separated into different genera based upon ultrastructural and biochemical characteristics (Essani \& Granoff 1989). EHNV has also been described as an iridovirus (Eaton et al. 1991) and, although it has not been compared directly with FLDV and GFV, it has been reported to be biochemically different from other piscine iridoviruses and ultrastructurally different from FLDV. Comparison of the polypeptide and DNA restriction enzyme digest profiles of EHNV with those described in the literature for other iridoviruses has indicated that EHNV is more closely related to the genus Ranavirus than to the 'goldfish virus group' (Eaton et al. 1991). 
Recently, an iridovirus termed 'Bohle virus' (BIV) has been isolated from the ornate burrowing frog Limnoclynastes ornatus (Gray) in Queensland, Australia (Speare \& Smith 1992). The virus was reported to vary in size from 137 to $172 \mathrm{~nm}$, contain methylated double stranded DNA and replicate in a variety of piscine and mammalian cell lines (Speare \& Smith 1992). Based on this information Speare \& Smith (1992) speculated that BIV was similar to EHNV and to ranaviruses such as FV3.

The isolation of BIV represents the second iridovirus isolated from aquatic species in Australia. Both viruses originated from organisms in environments with an overlapping geographical distribution. In this paper we compare the ultrastructural, protein and molecular characteristics of the above isolates. This information is used to ascertain whether both piscine and amphibian viruses belong to the same or different genera.

\section{MATERIALS AND METHODS}

Cells and viruses. Bluegill fry (BF-2, ATCC CCL 91) and chinook salmon embryo (CHSE-214, ATCC CRL 1681) cells were grown at $24^{\circ} \mathrm{C}$ and Vero cells (ATCC $\mathrm{CCL} 81$ ) at $37^{\circ} \mathrm{C}$ in Eagle's minimum essential medium (EMEM) containing $10 \%$ foetal calf serum (FCS) and $10 \mathrm{mM}$ HEPES. Aedes albopictus (C636. Australian National University, Canberra, Australia) cells were grown at $24{ }^{\circ} \mathrm{C}$ in basal medium of Eagle (BME) containing $1 \% \mathrm{FCS}$ and $1 \%$ non-essential amino acids. Baby hamster kidney (BHK-21) cells referred to hereafter as BHK (Commonweaith Seum Laboratories, Melbourne, Australia) were grown at $37^{\circ} \mathrm{C}$ in EMEM containing $10 \% \mathrm{FCS}, 10 \mathrm{mM}$ HEPES and $5 \%$ tryptose phosphate broth. Madin-Darby bovine kidney (MDBK, ATCC CCL 22) cells were grown at $37^{\circ} \mathrm{C}$ in EMEM containing $5 \%$ FCS and $10 \mathrm{mM}$ HEPES. Pig kidney 15 (PK15, ATCC CCL 33) cells were grown at $37^{\circ} \mathrm{C}$ in EMEM containing $5 \%$ FCS, $10 \mathrm{mM}$ HEPES and $4 \%$ sodium pyruvate.

Isolates of EHNV originally obtained from rainbow trout (EHNV ${ }_{T}$; Langdon 1989) and redfin perch (EHN$V_{R F i}$ Langdon et al. 1986) were plaque purified 3 times in BF-2 cells. Stock EHNV was grown in BF-2 and CHSE-214 cell monolayers. Following infection at a multiplicity of infection (MOI) of ca 0.1 plaque forming units (PFU) per cell and incubation for $48 \mathrm{~h}$ at room temperature (RT), cells and debris were removed by centrifugation and released virus in the culture medium (approximate titre $10^{5} \mathrm{PFU} \mathrm{ml}^{-1}$ ) was stored at $4{ }^{\circ} \mathrm{C}$. Following purification, as described below, stocks of intracellular (cell-associated) virus contained ca $10^{9} \mathrm{PFU} \mathrm{ml} \mathrm{m}^{-1}$.
An isolate of BIV obtained from Limnodynastes ornatus (Speare \& Smith 1992) was passaged 6 times in BF-2 cells. Following infection and incubation for $48 \mathrm{~h}$ at RT, cells and debris were removed by centrifugation and released virus in the culture medium (approximate titre $10^{6}$ PFU $\mathrm{ml}^{-1}$ ) was stored at $4^{\circ} \mathrm{C}$. Following purification as described below, stocks of intracellular

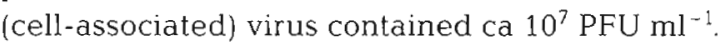

Purification of intracellular virus. Monolayers of CHSE-214 cells in sixty $150 \mathrm{~cm}^{2}$ tissue culture flasks were infected with released virus (EHNV or BIV) at a MOI of ca 0.1 PFU cell ${ }^{-1}$. At 48 h post infection (p.i.) cells were removed from the flasks and pelleted by centrifugation at $2600 \times g$ in a bench-top centrifuge for $10 \mathrm{~min}$. Pelleted cells were resuspended in $5 \mathrm{ml} \mathrm{RSB}$

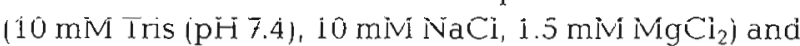
$0.5 \mathrm{ml} \mathrm{1,1,2-Trichlorotrifluoroethane} \mathrm{(Genitron)} \mathrm{and}$ lysed. Virus was sheared from the cytoskeleton in a motor-driven Dounce homogenizer and purified as described by Eaton et al. (1991).

Cell susceptibility. Stocks of EHNV $\mathrm{RF}, E H N V_{T}$ and $\mathrm{BIV}(100 \mu \mathrm{l})$ were added to monolayers of $\mathrm{C} 636$, BF-2, CHSE-214, Vero, BHK, MDBK and PK15 cells in $25 \mathrm{~cm}^{2}$ tissue culture flasks. The cells were incubated for $1 \mathrm{~h}$ at RT and excess virus removed by washing 4 times in PBS before the appropiate medium (refer above) was added. At 1, 2, 3, 4 and 8 d p.i. the cytopathic effect (CPE) was recorded. At Day 8 p.i. culture supernants were collected and analysed by enzyme-linked immunosorbent assays (ELISA) (refer below) for the presence of progeny viruses.

Enzyme linked immunosorbant assay (ELISA). The ELISA used in this study was based on that of Hyatt et al. (1991) and was used to determine if the virus isolates were replicating in the various cell types. The coating primary antibodies were sheep anti-EHNV (raised to whole virus, 1:30000) or sheep anti-EHNV $\mathrm{RF}_{\mathrm{RF}}$ (whole virus, 1:15000). Secondary antibodies con-

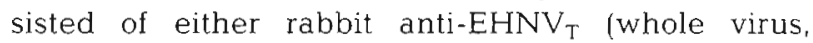

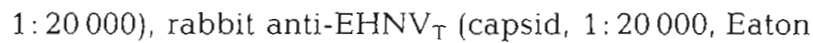

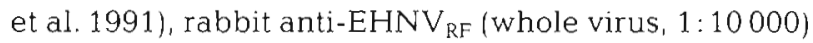
or rabbit anti-BIV (whole virus, 1:500). The antigens consisted of EHNV,$E H N V_{R F}$ or BIV at titers of: $4.5 \times 10^{7}, 2.2 \times 10^{7}$ and $1.0 \times 10^{7} \mathrm{PFU} \mathrm{ml}^{-1}$ respectively (Expt a); and $5.3 \times 10^{6}, 1.8 \times 10^{7}$ and $5.2 \times 10^{5} \mathrm{PFU} \mathrm{ml}^{-1}$ respectively (Expt b). When CPE was apparent the plates were read in a BIORAD Model 2550 EIA Reader at $450 \mathrm{~nm}$ and the data were recorded as optical densities (OD) of experimental sample less control. The control consisted of supernatants from uninfected cells which were processed as per experimental samples.

Electron microscopy. Negative contrast electron microscopy: Purified, cell-associated EHNV $\mathrm{RF}_{1} \mathrm{EHNV}_{\mathrm{T}}$ and BIV were adsorbed to copper grids and negatively stained with $2 \%$ phosphotungstic acid (PTA) adjusted 
to $\mathrm{pH} 6.8$ with $1 \mathrm{M} \mathrm{KOH}$. CHSE-214 cells were grown on carbon coated, filmed gold grids as described by Hyatt et al. (1987), infected with EHNV RF, EHNV $_{T}$ or BIV and stained at $24 \mathrm{~h}$ p.i. with $2 \%$ PTA adjusted to $\mathrm{pH} 6.8$ with $1 \mathrm{M} \mathrm{KOH}$

Thin section electron microscopy: BF-2 cells infected with $\mathrm{EHNV}_{\mathrm{RF}}$ or EHNV $\mathrm{T}$ were scraped and pelleted at 13 h p.i. CHSE-214 cells infected with EHNV RF $_{\text {or BIV }}$ were scraped and pelleted at $24 \mathrm{~h}$ p.i. Pellets were fixed in phosphate (Sorenson's) buffered $2.5 \%$ gluteraldehyde, washed with Sorenson's buffer, post-fixed in $1 \%$ osmium tetroxide, dehydrated in graded alcohols, infiltrated with propylene oxide and embedded in Polarbed 812 Epon resin. Ultra-thin sections were double stained in uranyl and lead citrate. Particles exhibiting a hexagonal outline were measured vertex to vertex. An Agar aids diffraction grating replica (2160 lines $\mathrm{mm}^{-1}$ ) was used to calibrate the magnification of the electron microscope.

Scanning electron microscopy: Cells (CHSE-214) were grown on glass coverslips and infected with both piscine and amphibian iridoviruses. At $18 \mathrm{~h}$ p.i., cells were fixed in cacodylate buffered $2.5 \%$ glutaraldehyde $(30 \mathrm{~min})$, washed in buffer $(3 \times 20 \mathrm{~min})$ post-fixed in buffered $1 \%$ osmium tetroxide $(1 \mathrm{~h})$, washed in double distilled water $(3 \times 5 \mathrm{~min})$ and dehydrated in graded ethanol. Following dehydration, cells were critically point dried from carbon dioxide and sputtercoated with gold. Samples were viewed with a JEOL JSM 840 at $20 \mathrm{kV}$

Immunoelectron microscopy: Purified, cell-associated EHNV $_{\mathrm{RF}}, \mathrm{EHNV}_{\mathrm{T}}$ and BIV were adsorbed to filmed nickel grids which were washed with PBS ( $3 \times 1 \mathrm{~min})$ and blocked with $5 \%$ cold-water fish gelatin (f.g.) in PBS for $10 \mathrm{~min}$. The grids were then placed in $1 \% \mathrm{f.g}$. for a further $10 \mathrm{~min}$ and incubated in either rabbit antiEHNV $_{\mathrm{T}}(1: 200)$, anti-EHNV RF $_{1}(1: 100)$ or anti-BIV (1:5) $1 \mathrm{~h}$ at RT. Grids were subsequently washed $(6 \times 3 \mathrm{~min})$ with $1 \% \mathrm{f.g}$. in PBS, incubated with protein A-gold (1:200 with $1 \%$ f.g. in PBS) for 1 h at RT and then washed in PBS $(3 \times 1 \mathrm{~min})$. The grids were post-fixed in $2.5 \%$ gluteraldehyde ( $2 \mathrm{~min})$, washed in water $(3 \times 3 \mathrm{~min})$, and stained with $1 \%$ aqueous uranyl acetate for $30 \mathrm{~s}$

Analysis of viral proteins from infected cells and purified virus. BIV-Infected cells: BIV was adsorbed to CHSE-214 cells at a MOI of $0.1 \mathrm{PFU} \mathrm{cell}^{-1}$ in a $25 \mathrm{~cm}^{2}$ tissue culture flask for $1 \mathrm{~h}$ at $24^{\circ} \mathrm{C}$. At $16 \mathrm{~h}$ the growth medium was removed and replaced with methionine-free EMEM containing $24 \mu \mathrm{Ci} \mathrm{ml}{ }^{-1}\left[{ }^{35} \mathrm{~S}\right]$ methionine. After labelling for $1 \mathrm{~h}$ at $24^{\circ} \mathrm{C}$, the medium containing the radioactive methionine was removed and cells were washed with PBS, scraped into lysis buffer [125 mM Tris (pH 6.5), $2 \%$ sodium dodecyl sulphate (SDS), $20 \mathrm{mM}$ dithiothreitol, $10 \%$ glycerol and $0.5 \%$ bromophenol blue] and frozen at $-20^{\circ} \mathrm{C}$.
${ }^{35}$ S]-methionine labelled virus: Cells (CHSE-214) were infected with each virus isolate as described above. At ca 20 h p.i., cells were washed with PBS and the medium replaced by methionine-free EMEM containing $50 \mu \mathrm{Ci} \mathrm{m} \mathrm{m}^{-1}\left[{ }^{35} \mathrm{~S}\right]$-methionine. At ca $24 \mathrm{~h}$ p.i. cells were scraped from 4 labelled and 6 unlabelled flasks, pelleted and purified as described. Lysis buffer $(7.5 \mu \mathrm{l})$ was then added to $30 \mu \mathrm{l}$ of pelleted, dialysed virus.

All samples were boiled for $90 \mathrm{~s}$ prior to loading onto $10 \%$ polyacrylamide gels (Laemmli 1970). Following electrophoresis, gels were dried and the $\left.\right|^{35} \mathrm{~S}$-labelled proteins detected by autoradiography. $\left[{ }^{14} \mathrm{C}\right.$-labelled marker proteins included in each gel were purchased from Amersham.

Western blotting. Viruses were purified as described above. Prior to loading on $10 \%$ polyacrylamide gel (Laemmli 1970), $10 \mu \mathrm{l}$ of the virus $\left(\mathrm{EHNV}_{\mathrm{RF}}, \mathrm{EHNV}_{\mathrm{T}}\right.$ or BIV) from the supernatant of lysed and dounced CHSE-214 cells were mixed with $3 \mu \mathrm{l}$ of a DTT mixture (325 mM dithiothreitol, $25 \%$ bromophenol blue, $45 \%$ glycerol in $0.25 \mathrm{M}$ Tris $\mathrm{HCl} \mathrm{pH} \mathrm{6.5)} \mathrm{and} \mathrm{SDS} \mathrm{to} \mathrm{a}$ final concentration of $2 \%$ and then boiled for $5 \mathrm{~min}$ Following electrophoresis proteins were transferred to nitrocellulose using a BIO-RAD transfer apparatus. The nitrocellulose was blocked overnight in $1 \%$ skim milk in TBS (150 mM NaCl, $80 \mathrm{mM}$ Tris-HCl pH 7.4) after which either rabbit anti-EHNV (whole virus) diluted $1: 300$, rabbit anti-EHNV $V_{T}$ (capsid) diluted

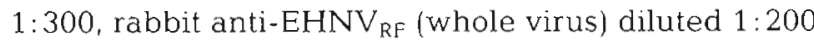
or rabbit anti-BIV (whole virus) diluted 1:5 in 1\% skim milk was applied for $1 \mathrm{~h}$ at RT. After washing 3 times in TBST $(150 \mathrm{mM} \mathrm{NaCl}, 80 \mathrm{~m} \mathrm{M}$ Tris-HCl pH 7.4, $0.05 \%$ Tween 20) the nitrocellulose was incubated with anti-rabbit IgG (FC) alkaline phosphatase conjugate (Promega $1 \mathrm{mg} \mathrm{ml}^{-1}$ ) diluted 1:7000 in 1\% skim milk for $1 \mathrm{~h}$ at RT. The nitrocellulose was washed in AP buffer $(100 \mathrm{mM}$ Tris $\mathrm{pH} 7.4,100 \mathrm{mM} \mathrm{NaCl}, 5 \mathrm{mM}$ $\mathrm{MgCl}_{2}$ ) and developed with protoblot system substrate for $10 \mathrm{~min}$ in the dark. The reaction was stopped with water.

DNA purification and cross-hybridization. Dialysed, purified $E H N V_{R F}, E H N V_{T}$ and BIV were adjusted to $0.1 \mathrm{M} \mathrm{NaCl}, 5 \mathrm{mM}$ EDTA, $26 \%(\mathrm{w} / \mathrm{v})$ sucrose and $1 \%$ SDS and mixed by rolling at $4{ }^{\circ} \mathrm{C}$ for $30 \mathrm{~min}$. Proteinase $\mathrm{K}$ to a final concentration of $100 \mu \mathrm{g} \mathrm{ml}^{-1}$ and ribonuclease A to $40 \mu \mathrm{g} \mathrm{ml}^{-1}$ were added and the incubation continued at $37^{\circ} \mathrm{C}$ for $18 \mathrm{~h}$. Each solution was extracted twice with an equal volume of phenol : chloroform (1:1) and once with chloroform. Sodium acetate was added to $0.2 \mathrm{M}$ followed by 2.5 volumes of ice cold ethanol. Precipitated DNA was spooled out, dried briefly under vacuum and resuspended with $10 \mathrm{mM}$ Tris-HC1 pH 7.5, to a concentration of 0.5 to $1.0 \mu \mathrm{g} \mathrm{ml}^{-1}$. Restriction enzyme digests, agarose gel electro- 
phoresis and field inversion gel electrophoresis were carried out as described in Coupar et al. (1990).

For cross-hybridization studies 5-fold dilutions of sonicated DNA (from EHNV RT, EHNV $_{T}$, BIV, vaccinia virus and calf thymus) in $10 \times \mathrm{SSC}$ were denatured at $95^{\circ} \mathrm{C}$ for $10 \mathrm{~min}$, cooled on ice and loaded onto duplicate GeneScreenPlus (NEN) membranes using a 96 well manifold. The initial amount of DNA added was $0.5 \mu \mathrm{g}$. Prehybridized membranes were hybridized with nick translated ${ }^{32} \mathrm{P}$-labelled DNA (from EHNV $_{\mathrm{RT}}$ or BIV) overnight at $42^{\circ} \mathrm{C}$ in buffer containing $50 \%$ formamide. Membranes were washed with $2 \times \mathrm{SSC} / 0.1 \% \mathrm{SDS}$ followed by $0.1 \times \mathrm{SSC} 10.1 \% \mathrm{SDS}$ at $60^{\circ} \mathrm{C}$ and exposed to $\mathrm{X}$-ray film.

\section{RESULTS}

\section{Cell susceptibility}

BF-2 and CHSE-214 cells were infected with EHNV RF, EHNV $_{T}$ and BIV. Although advanced CPE could be observed in all infected cultures by 3 d p.i., there was a discernable difference between that of piscine and amphibian virus-infected cells (Fig. 1). EHNV RFT $_{\text {produced defined }}$ plaques which were circular and punctate in appearance (Fig. 1A). Cells associated with the perimeter of these plaques frequently possessed long cellular processes extending from a rounded cell body which contained characteristic large inclusion bodies detectable by phase light microscopy (data not shown). Following cell rounding and formation of the cellular processes, cells detached from the substrate forming the characteristic plaques. The plaques formed in BIV-infected cultures differed from those produced by EHNV $V_{\text {RF.T }}$ in that they were diffuse (Fig. 1B). Within these cultures, infected cells became round, but did not produce the same long cellular processes. Inclusion bodies were also apparent, but the cells did not always detach from the substrate and produced only indistinct plaques. The differences in CPE were consistent over a range of MOI and are therefore considered to represent fundamental differences in virus replication as opposed to differences in the kinetics of virus replication.

Of the mammalian cell lines which were infected with the 3 virus isolates, Vero and BHK cells exhibited the most advanced CPE by Day 3 p.i. CPE was less dramatic in the MDBK and PK15 cell lines. Insect cells
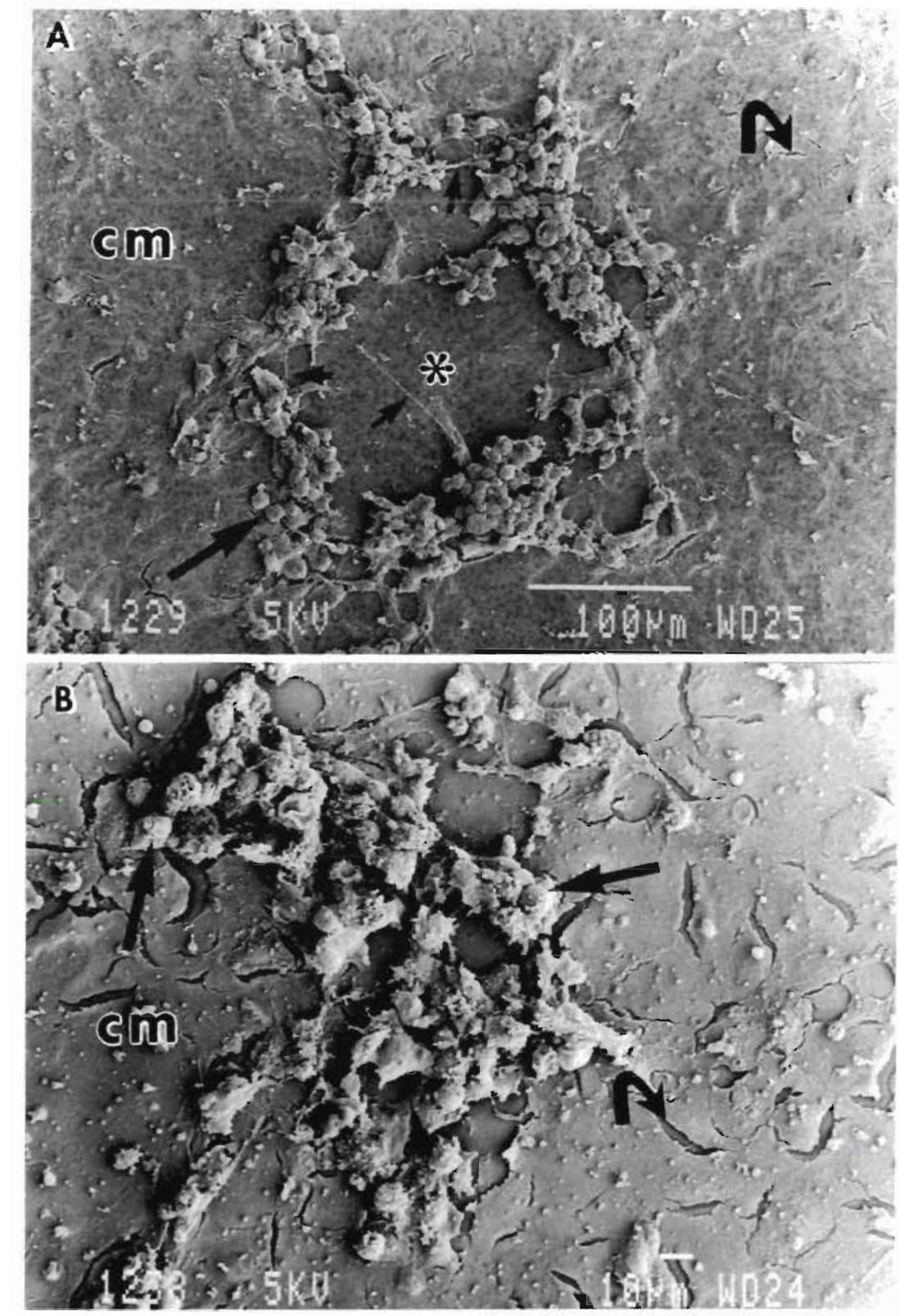

Fig. 1. Scanning electron micrographs of monolayers $(\mathrm{cm})$ of CHSE cells infected with EHNV (represented by EHNV ) and BIV. (A) The punctate CPE (*) is obvious in cells infected with EHNV, the long cellular processes are indicated by short arrows and the rounded cell by long arrows. Scale bar $=100 \mu \mathrm{m}$. (B) CPE incurred by BIV. The CPE is more diffuse, most of the cells have rounded (large arrows) and few if any long cellular processes can be seen. Scale bar $=10 \mu \mathrm{m}$. [Cracks in

the cell monolayers (bent arrows) are artifacts of specimen preparation] 
(C636) infected with EHNV $\mathrm{RF}, \mathrm{EHNV}_{\uparrow}$ or BIV failed to show any signs of CPE. The ability of the viruses to infect the different cell lines was assessed by ELISA using antiserum raised against whole EHNV . Fig. 2 shows optical densities obtained with the supernatants of cells infected with the different virus isolates. With the exception of cell line C636, all samples were positive suggesting that the CPE was due to virus replication.

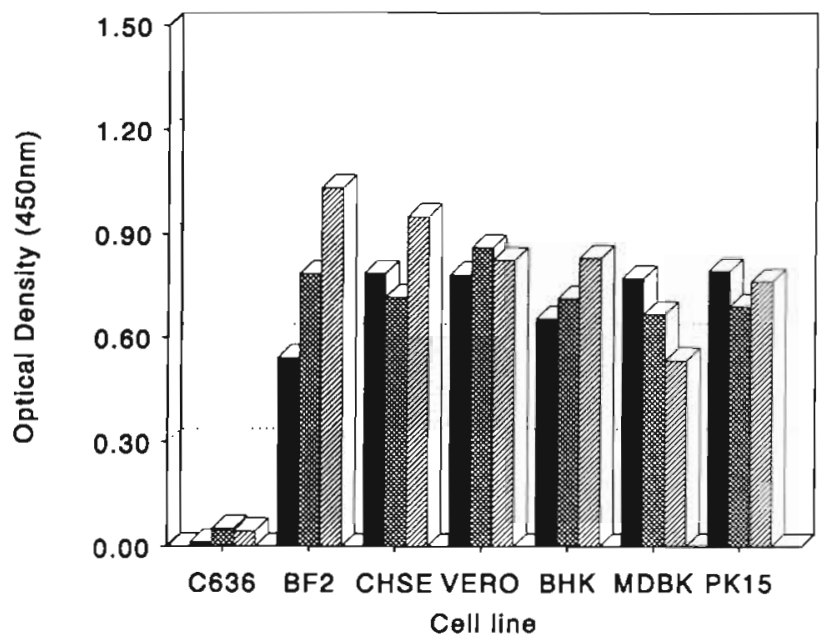

Fig. 2. ELISA results from the supernatant of cells infected

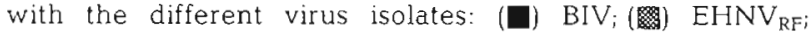
(שת) EHNV . The supernatants were collected after advanced CPEs were observed. Results are expressed as optical densities of infected minus control supernatants. Plates were coated with sheep ant1-EHNV (whole virus) $^{-}$

\section{Antigenicity}

ELISA results. CHSE-214 cells were inoculated with $\mathrm{EHNV}_{\mathrm{RF}}, \mathrm{EHNV}_{\mathrm{T}}$ and BIV. At $48 \mathrm{~h}$ p.i. the supernatants were removed and stored at $4{ }^{\circ} \mathrm{C}$ prior to analysis by ELISA. The supernatants were added to ELISA plates which had been previously coated with sheep polyclonal antibodies directed against (1) EHNV E $_{T}$ and (2) EHNV RF. The secondary antibodies comprised rabbit polyclonal antisera directed against (3) EHNV (whole virus), (4) EHNV $_{T}$ (capsid),

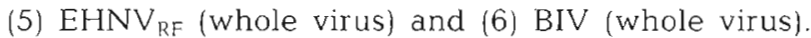
All isolates yielded positive results (Table 1) with their homologous and heterologous antisera. In both assay systems EHNV $V_{T, R F}$ isolates gave stronger positive results against anti-EHNV than anti-BIV antibodies (Table 1). The results indicate a high degree of crossreactivity between any one antiserum and the different Australian iridoviruses.

Immunoelectron microscopy. Purified EHNV $\mathrm{RF}$, EHNV $_{\text {TF }}$ and BIV were adsorbed to carbon-coated, filmed gold grids and incubated with antisera generated against EHNV,$E_{T} \mathrm{ENV}_{\mathrm{RF}}$ and BIV. Representative results are shown in Fig. 3. All isolates reacted with the 3 antisera. No difference in the pattern and/or intensity of immunostaining could be discerned between the isolates incubated in the presence of any one antiserum.

\section{Electron microscopy}

Negative contrast electron microscopy (NCEM). Ultrastructurally, EHNV $\mathrm{RF}, \mathrm{EHNV}_{\mathrm{T}}$ and BIV were very similar. Complete virions possessed outer envelopes (Fig. 3). This outer envelope encompassed an inner capsid, which has been shown previously

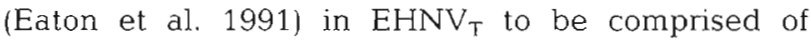
capsid subunits containing a $51 \mathrm{kD}$ protein and a lipid membrane. When infected cells were extracted with a non-ionic detergent (NP40), viruses were observed to be associated with the filamentous framework of the cytoskeleton (data not shown). Grid-cell-cultures of infected cells showed that EHNV isolates budded from the plasma membrane (Fig. 4A), particularly along the long cellular processes of infected cells. In BIV-infected cells where extended cell processes were absent, budding

Table 1. Representative ELISA optical densities at $450 \mathrm{~nm}$ for the various isolates captured by antibodies against EHNV and EHNV $V_{\mathrm{RF}}$. Values represent (sample - uninfected control)

\begin{tabular}{|c|c|c|c|c|}
\hline \multirow[t]{2}{*}{$1^{\circ}$ antibody } & \multirow[t]{2}{*}{$2^{\circ}$ antibody } & \multicolumn{3}{|c|}{ Optical density } \\
\hline & & $\mathrm{EHNV}_{\mathrm{RF}}$ & $\mathrm{EHNV}_{\mathrm{T}}$ & BIV \\
\hline \multirow[t]{4}{*}{ Sheep anti-EHNV (whole virus) } & Rabbit anti-EHNV (whole virus) & 1.532 & 1.321 & 0.742 \\
\hline & Rabbit anti-EHNV ${ }_{T}$ (capsid) & 1.462 & 1.277 & 0.743 \\
\hline & Rabbit anti-EHNV $V_{R F}$ (whole virus) & 1.432 & 1.744 & 1.132 \\
\hline & Rabbit anti-BIV (whole virus) & 0.220 & 0.271 & 0.122 \\
\hline \multirow[t]{4}{*}{ Sheep anti-EHNV $\mathrm{RF}_{\text {(whole virus) }}$} & Rabbit anti-EHNV (whole virus) & 1.114 & 1.382 & 1.272 \\
\hline & Rabbit anti-EHNV (capsid) & 1.384 & 1.216 & 0.979 \\
\hline & Rabbit anti-EHNV ${ }_{R F}$ (whole virus) & 1.651 & 1.754 & 1.479 \\
\hline & Rabbit anti-BIV (whole virus) & 0.231 & 0.264 & 0.235 \\
\hline
\end{tabular}



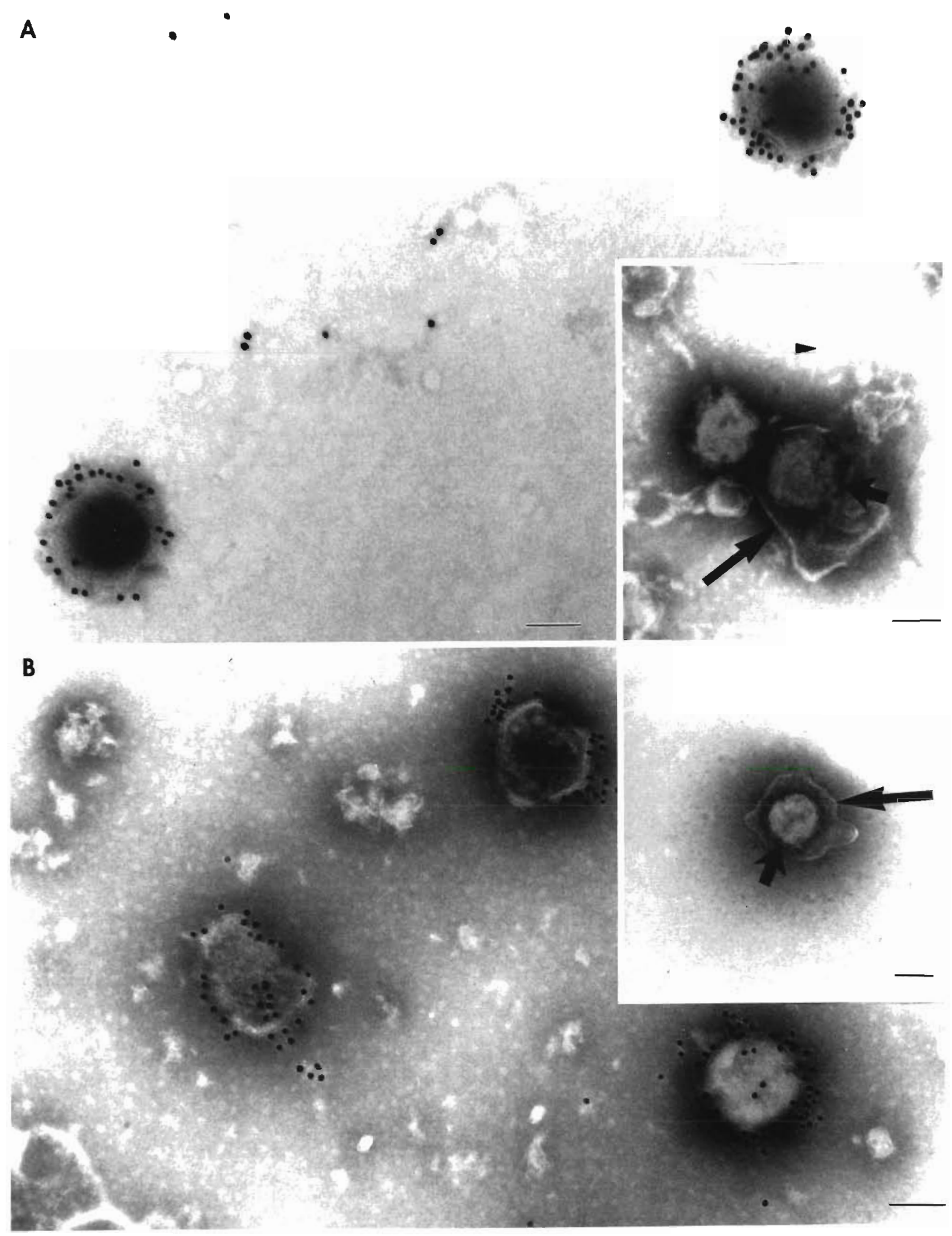
Fig. 3. Negatively stained and gold-labelled BIV and EHNV. Each of the isolates was labelled with each antiserum. (A) EHNV (representative of both piscine isolates) incubated in the presence of anti-BIV antibodies and protein A-gold. Inset: negative stained preparation of EHNV . The host-cell-derived envelope (large arrow) and inner core surrounded by capsid subunits (short arrow) are indicated. (B) BIV incubated in the presence of anti-EHNV $V_{T}$ antibody and protein A-gold A similar result was ob-

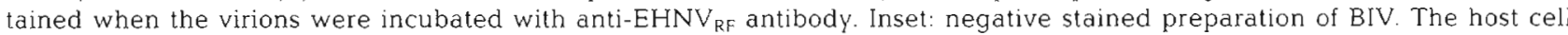
membrane (large arrow) and capsid subunits (short arrows) are indicated. Scale bars $=100 \mathrm{~nm}$

occurred from the body of the host cell (Fig. 4B). The sizes (diameters) of the virions were not measured in NCEM samples as this could lead to spurious results due to degeneration of viruses and variation in size due to air drying.

Thin section electron microscopy. The ultrastructure of $E H N V_{R F}$ and $E H N V_{T}$-infected cells was very similar. EHNV $V_{R F}$ and BIV-infected cells were compared. Infected cells possessed lobate nuclei with marginated heterochromatin and a disorganised cytoplasm. Within the cytoplasm, non-membrane bound viral inclusion bodies (VIB) appeared as rarified areas. These electron translucent structures were devoid of cellular organelles (Fig. 5). Another prominent feature of the cytoplasm was the aggregation of mitochondria around the perimeter of the
VIB. Within the VIB, areas of condensation, presumably DNA (Murti et al, 1985b), were frequently observed (data not shown). These electron dense areas were usually associated with developing virus particles. Crystalline arrays of virions (Fig. 5) were observed in all infected cells and these were located both within the VIB and the cytoplasmic matrix. In addition to crystalline arrays, individual virus particles were observed in the cytoplasm in lysosomes and budding from the host cell plasma membrane. Within the inclusion bodies, virions were observed in different stages of assembly (e.g capsid fragments, incomplete and complete capsids). No major differences in replication strategies were noted for any one virus in different host cells, namely BF-2 and CHSE-214 cells.
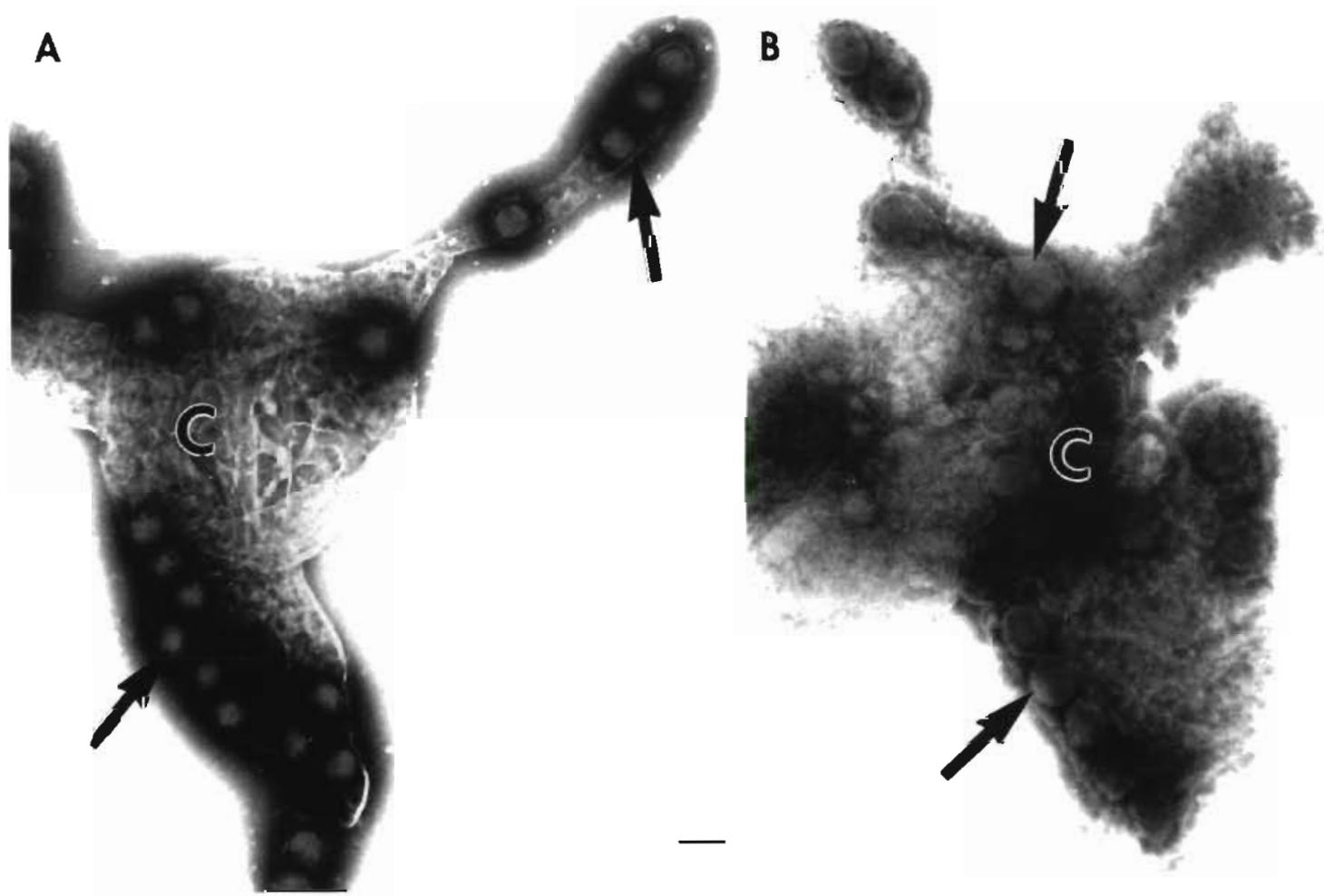

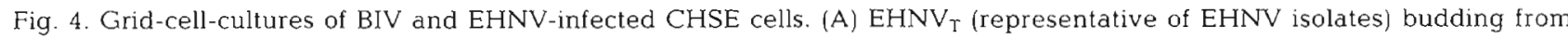
extended cellular processes of an infected cell (C). (B) BIV budding from an infected cell. No long cellular processes are present. Scale bars $=100 \mathrm{~nm}$ 


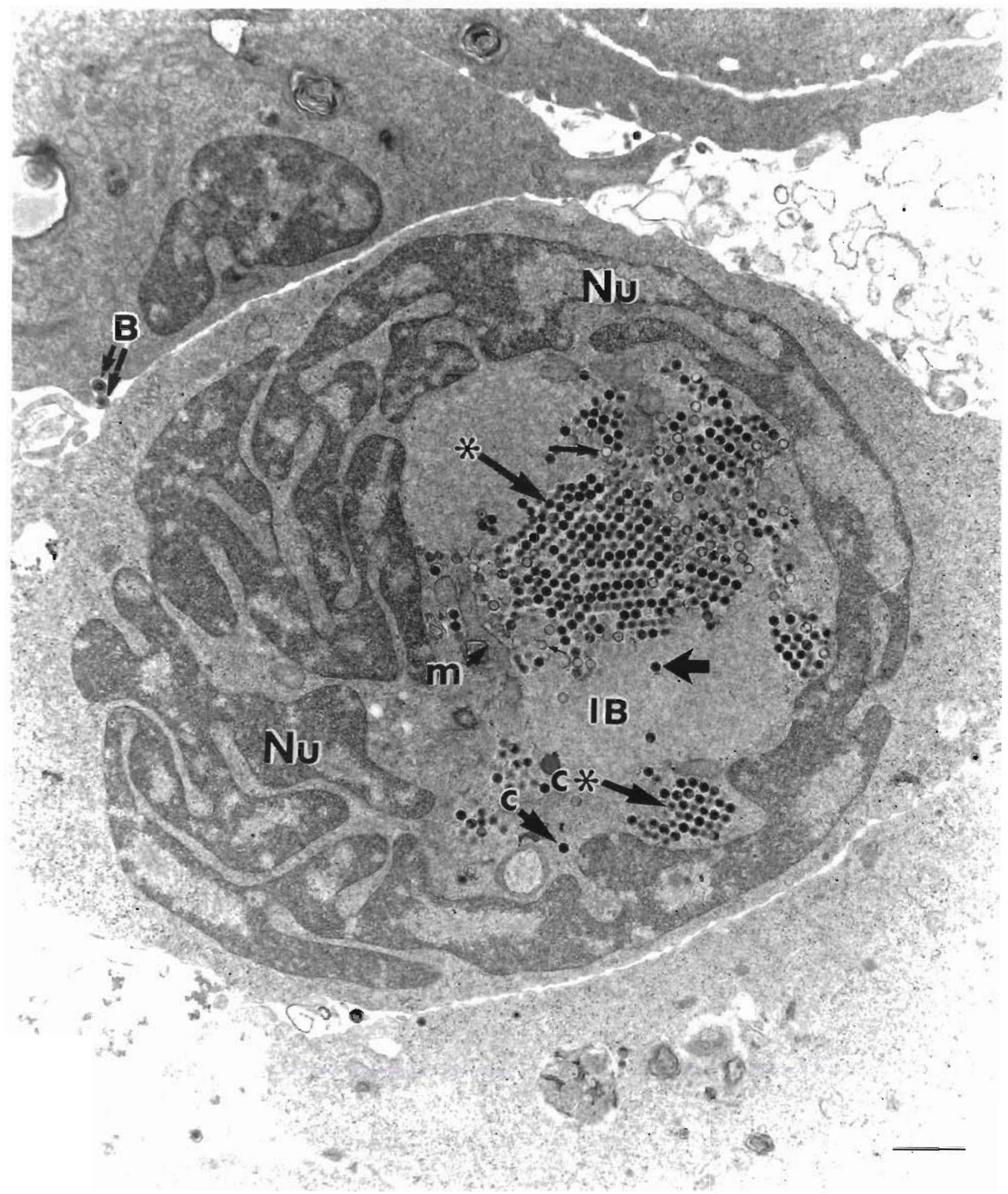

Fig 5 Transmission electron micrograph of a BIV-infected CHSE cell Only 1 micrograph is included as it is representative of the overall ultrastructure of cells infected with all 3 isolates $\mathrm{Nu}$ nucleus, $\mathrm{m}$ mitochondria; IB: inclusion body (viroplasm); * paracrystalline array of IB-associated viruses, $c *$ paracrystallıne array of cytoplasmic viruses; c: individual cytoplasmic viruses. B viruses buddıng from the host cell membrane Scale bar $=1 \mu \mathrm{m}$ 
Table 2. Size of EHNV and BIV calculated from intracellular arrays

\begin{tabular}{|c|c|c|}
\hline & $\begin{array}{l}\text { Size of EHNV } V_{R F} \text { in } \\
\text { CHSE cells }(n m)\end{array}$ & $\begin{array}{l}\text { Size of BIV in } \\
\text { CHSE cells (nm) }\end{array}$ \\
\hline No. of values & 100 & 102 \\
\hline Mean $\pm \mathrm{SD}$ & $172 \pm 6$ & $159 \pm 6$ \\
\hline$t$-value $(\mathrm{df}=200)$ & \multicolumn{2}{|c|}{14.708} \\
\hline
\end{tabular}

The electron micrographs of virus particles in the cytoplasmic crystalline arrays were used to calculate the diameters of the virions for each of the 3 isolates. No major differences were observed between $\mathrm{EHNV}_{\mathrm{RF}}$

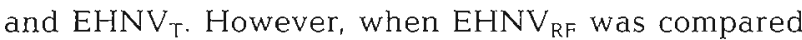
to BIV (Table 2) the virions of BIV were found to be significantly smaller.

As shown using the grid-cell-culture technique, viruses were released from the cell by budding (Fig. 4). They appeared to approach areas of host membrane where evagination of a thickened trilaminar membrane indicated the beginning of the budding process. However, as was observed in the negative stained preparations, EHNV frequently budded from extended cellular processes whereas BIV budded from the body of the cell.

\section{Polypeptides synthesised in EHNV- and BIV-infected cells}

Cells infected with EHNV and BIV induced a rapid inhibition of host cell protein synthesis (data not shown) and the synthesis of numerous virus-specific proteins. Intracellular BIV proteins determined by polypeptide gel electrophoresis are shown in Fig. 6A. The autoradiograph shows the presence of at least 20 polypeptides with molecular weights (MW) estimated to range from 22 to $123 \mathrm{kD}$. The number and size of BIV-specific proteins resembled that described for EHNV and FV3-infected cells (Willis et al. 1977, Elliot \& Kelly 1980, Eaton et al. 1991). Fig. 6B shows the polypeptides in purified BIV and EHNV. Comparison of the BIV proteins in cells and purified viruses (Fig. 6A, B, Lane 4) reveals that specific proteins (e.g. 27, 35, 54,57, 81 and $111 \mathrm{kD}$ ) were not present in purified virus and may represent nonstructural proteins. Conversely a $92 \mathrm{kD}$ protein was detected in purified BIV, but not amongst the intracellular proteins. The reason for this may reflect the amount of methionine in the protein and its comparative level amongst the cell-associated proteins or additional processing before incorporation into the virions.
Fig. 6B shows the polypeptide compositions of

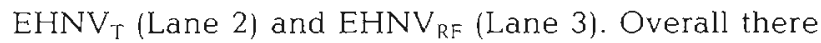
were only a few apparent differences between the profiles of the 2 piscine isolates. For EHNV there were additional $37 \mathrm{kD}$ and possible $82 \mathrm{kD}$ proteins. However, these differences may be a reflection of the low amounts of proteins present and thus the inability to detect them may be a quantitative problem These differences are also apparent in Fig. 7. In contrast EHNV RF $_{\text {differed from }} \mathrm{EHNV}_{\mathrm{T}}$ in the presence of (1) additional $31 \mathrm{kD}$ and $88 \mathrm{kD}$ proteins and (2) the presence of a $72 \mathrm{kD}$ compared to a $73 \mathrm{kD}$ in EHNV

The differences in polypeptide profiles between BIV and the EHNV isolates were more pronounced The major differences were the presence of 99,92 , $61,49,43,36,30$ and $26 \mathrm{kD}$ proteins in purified BIV. Some of these proteins may be analogous to the 101 , $88,60,51,35$ and $29 \mathrm{kD}$ proteins from purified EHNV isolates. There did not appear to be any analogous EHNV proteins for the 43 or $26 \mathrm{kD}$ proteins The polypeptide profile of BIV also differed from that of the EHNV profiles in the apparent absence of proteins analogous to the $86,82,37$ and $31 \mathrm{kD}$ proteins of EHNV.

\section{Western blot analyses}

A coommassie-blue-stained mini-gel of SDS-treated, purified EHNV $\mathrm{RE}_{\mathrm{T}}$ and BIV is shown in Fig. 7. This figure is representative of gels from which proteins were transferred to nitrocellulose and serves as a visual aid for the interpretation of the following blots. Minor discrepancies in calculated MW of specific polypeptides shown in Figs. 6, 7 or 8 for any one isolate can be attributed to differences in gel sizes and or running conditions.

Proteins from the 3 viruses reacted with homologous and heterologous antisera (Fig. 8). The antiserum used in Fig. 8A was raised to the $51 \mathrm{kD}$ capsid protein (Fig. 6B) of $\mathrm{EHNV}_{\mathrm{T}}$ (Eaton et al. 1991). This antiserum reacted strongly with the homologous proteins of EHNV,$E_{T} \mathrm{EHV}_{\mathrm{RF}}$ and with a $49 \mathrm{kD}$ protein of BIV and to a lesser extent with a $44 \mathrm{kD}$ protein (Fig. 8A, Lane 1). EHNV proteins of MW 44 and $38 \mathrm{kD}$ were also recognised by this antiserum. It is interesting to note that whilst the $38 \mathrm{kD}$ protein of EHNV was readily detected in Western blots of EHNV, it was not apparent in stained gels of virus proteins (Figs. 6B \& 7). Proteins from the 3 virus isolates which were probed with antiserum raised

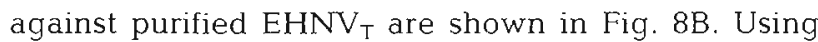
this serum, the 50 and $44 \mathrm{kD}$ proteins were less intensely stained and the $38 \mathrm{kD}$ protein was only 
slightly apparent. Whilst there were subtle differences between the piscine isolates in Fig. 8B (e.g. 82, 76 and $38 \mathrm{kD}$ proteins), more pronounced differences can be seen in Fig. $8 \mathrm{C}$ where the SDS-treated proteins have been reacted with antiserum raised against whole purified EHNV $\mathrm{RF}_{\mathrm{R}}$. The differences are highlighted by the comparatively intense $38 \mathrm{kD}$ $\mathrm{EHNV}_{\mathrm{T}}$ and $45 \mathrm{kD}$ EHNV $\mathrm{RF}$ protein. Whilst many BIV proteins reacted with antibodies to the piscine viruses, the EHNV and BIV profiles differed in the presence of a more intensely stained $112 \mathrm{kD}$ protein in BIV (Fig. 8B), the absence of many of the minor immunostained proteins (e.g. 76, 61, 42 and $38 \mathrm{kD}$ ) and the absence of a major analogous $50 \mathrm{kD}$ protein when incubated with antiserum raised against purified EHNV $_{\mathrm{T}}$. The blot in Fig. 8D shows the reaction of SDS-treated proteins with polyclonal antiserum raised against BIV. This antiserum produced a very weak homologous response but the blot is included as it illustrates the ability of the antiserum to react with heterologous EHNV proteins. Anti-BV antiserum detected proteins of apparent MW 93 and $50 \mathrm{kD}$ in $B V, E H N V_{T}$ and $E H N V_{R F}$. Proteins from uninfected CHSE-214 cells failed to react with the antisera used in these experiments (data not shown) as did infected cells with normal (control) sera.
A

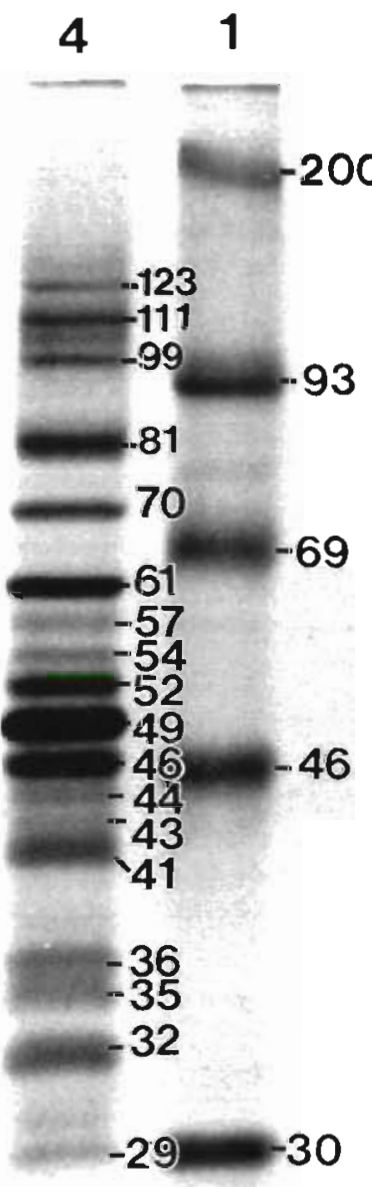

$-27$

26
B

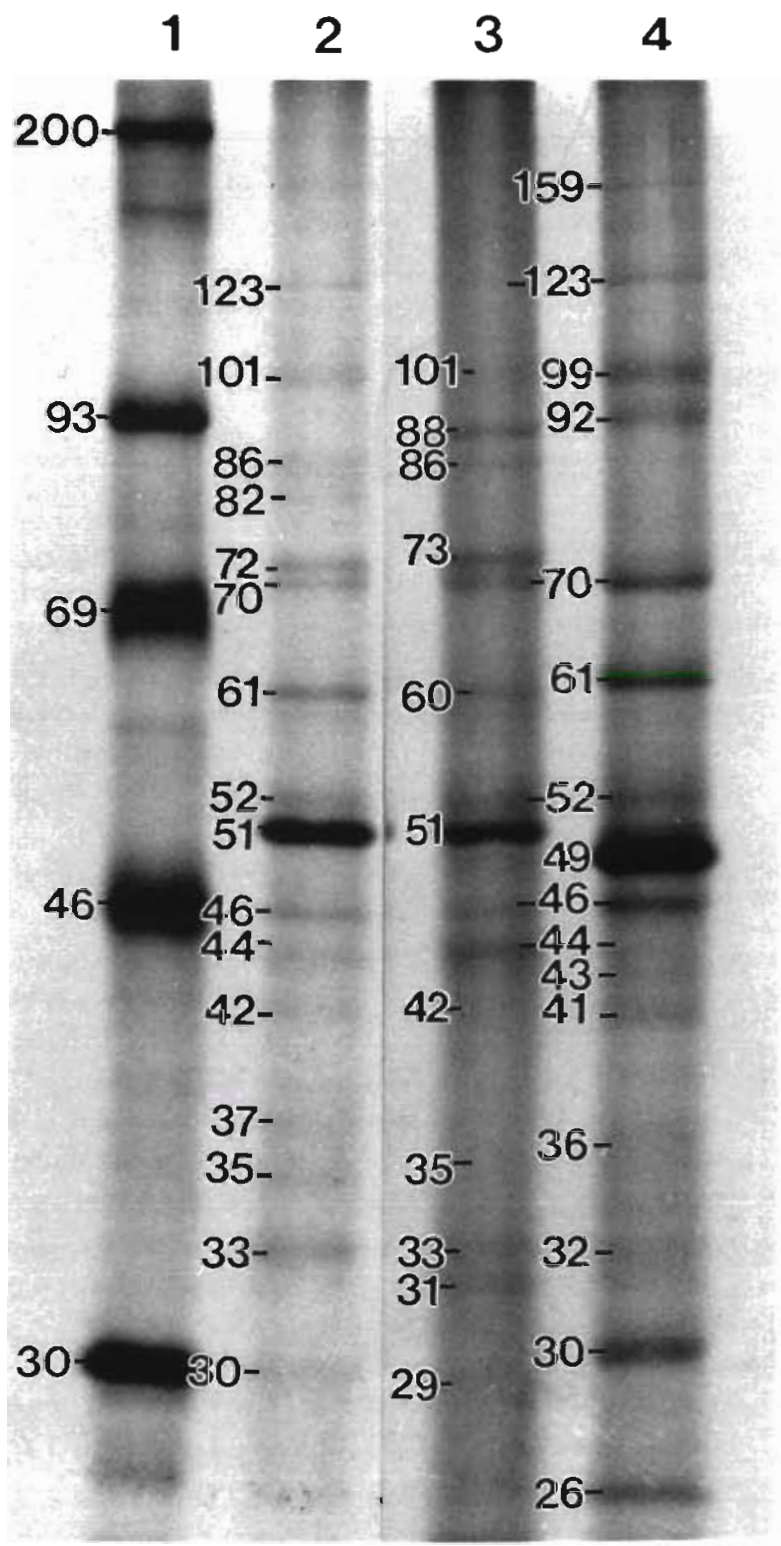

Fig. 6. Proteins in (A) BIV-infected cells and (B) purified EHNV ${ }_{T}$ EHNV $_{\mathrm{RF}}$ and BIV with estimated molecular weights $(\mathrm{kD})$. Radioactively labelled proteins in Lanes 1 to 4 were detected by autoradiography. Lane 1: markers; Lane 2: $\mathrm{EHNV}_{\mathrm{T} i}$ Lane 3: $\mathrm{EHNV}_{\mathrm{RF}}$ Lane 4: BIV 


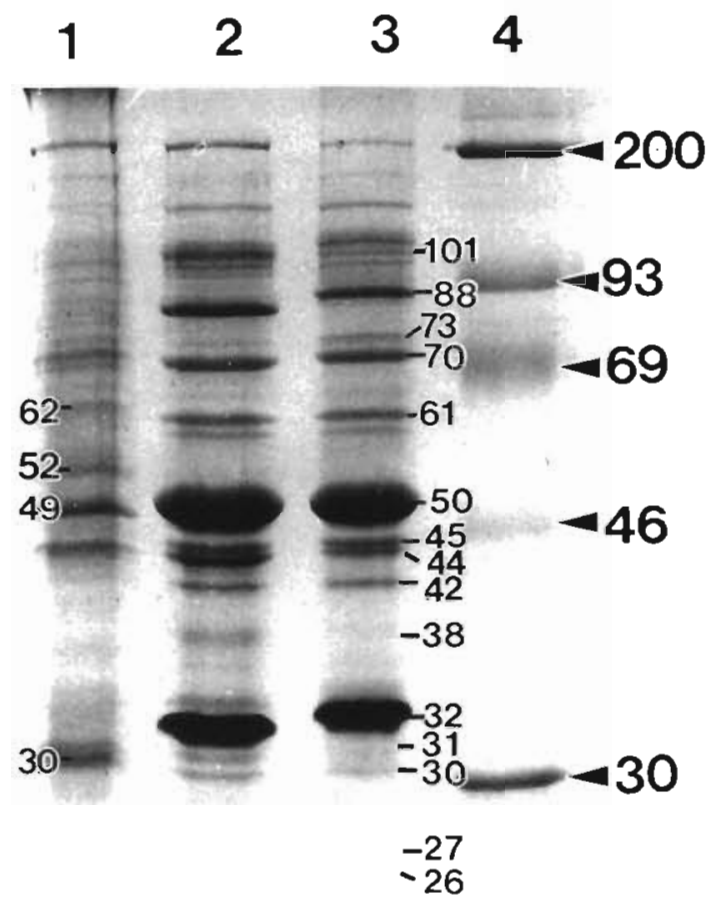

$-22$

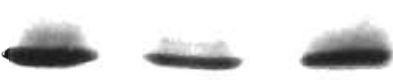

Fig. 7. Proteins in purified viruses from infected cells. This coommassie-blue-stained mini-gel of SDS-treated virus is included as it is representative of the proteins transferred to nitrocellulose and facilitates the interpretation of the Western blots (Fig. 8). Molecular weights (kD) were estimated by reference to stained markers (Lane 4) run in the same gel. Lane 1: BIV; Lane 2: EHNV Lane 3: EHNV $\mathrm{RF}_{\text {. }}$ (For the EHNV profiles the 61, 92 and $116 \mathrm{kD}$ proteins are non-structural; Eaton et al. 1991)

Fig. 8. Western blot analyses of proteins illustrated in Fig. 7. Blots using uninfected CHSE cells as antigen with normal serum in lieu of antibody are not included as these did not generate any bands. Molecular weights were estimated by reference markers run in the original gel and transferred to nitrocellulose (not shown). The Western blots indicate proteins reactive with (A) antisera raised against the 51-52 kD capsid protein of EHNV (B) antisera raised against whole $E_{N N V_{R F}}$ (C) antisera raised against whole $\mathrm{EHNV}_{\mathrm{T}}$; (D) antisera raised against BIV. In all profiles, Lane 1 contains BIV, Lane 2, EHNV ${ }_{\mathrm{T}}$ Lane 3, EHNV $\mathrm{RF}$

\section{Restriction endonuclease analyses and cross hybridization}

Comparison of restriction enzyme profiles for EHNV and BIV DNAs showed different patterns for digests with KpnI, BamHI, HindIII and NCoI (Fig. 9) and for
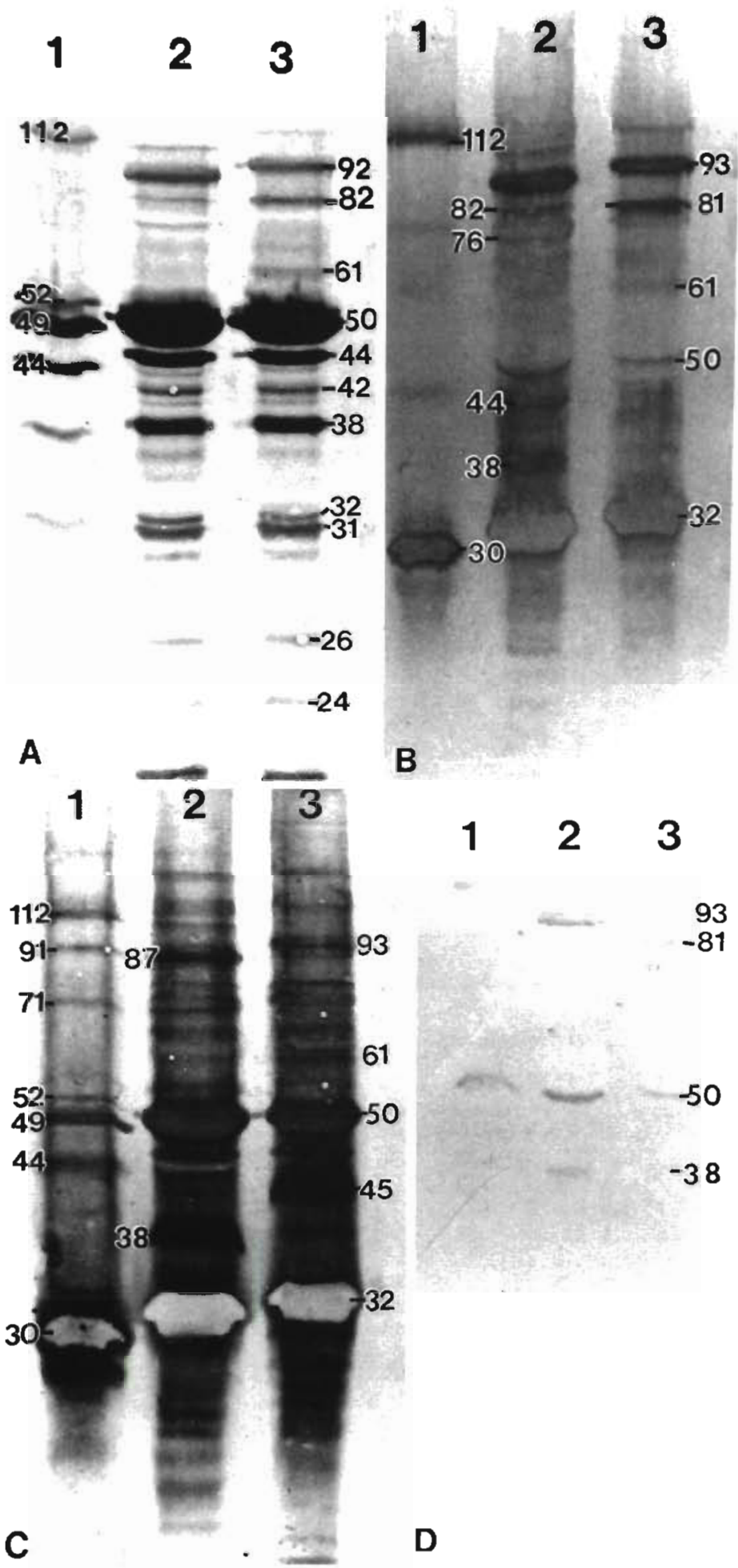


\section{Kpnl BamHI HindIII Neol}

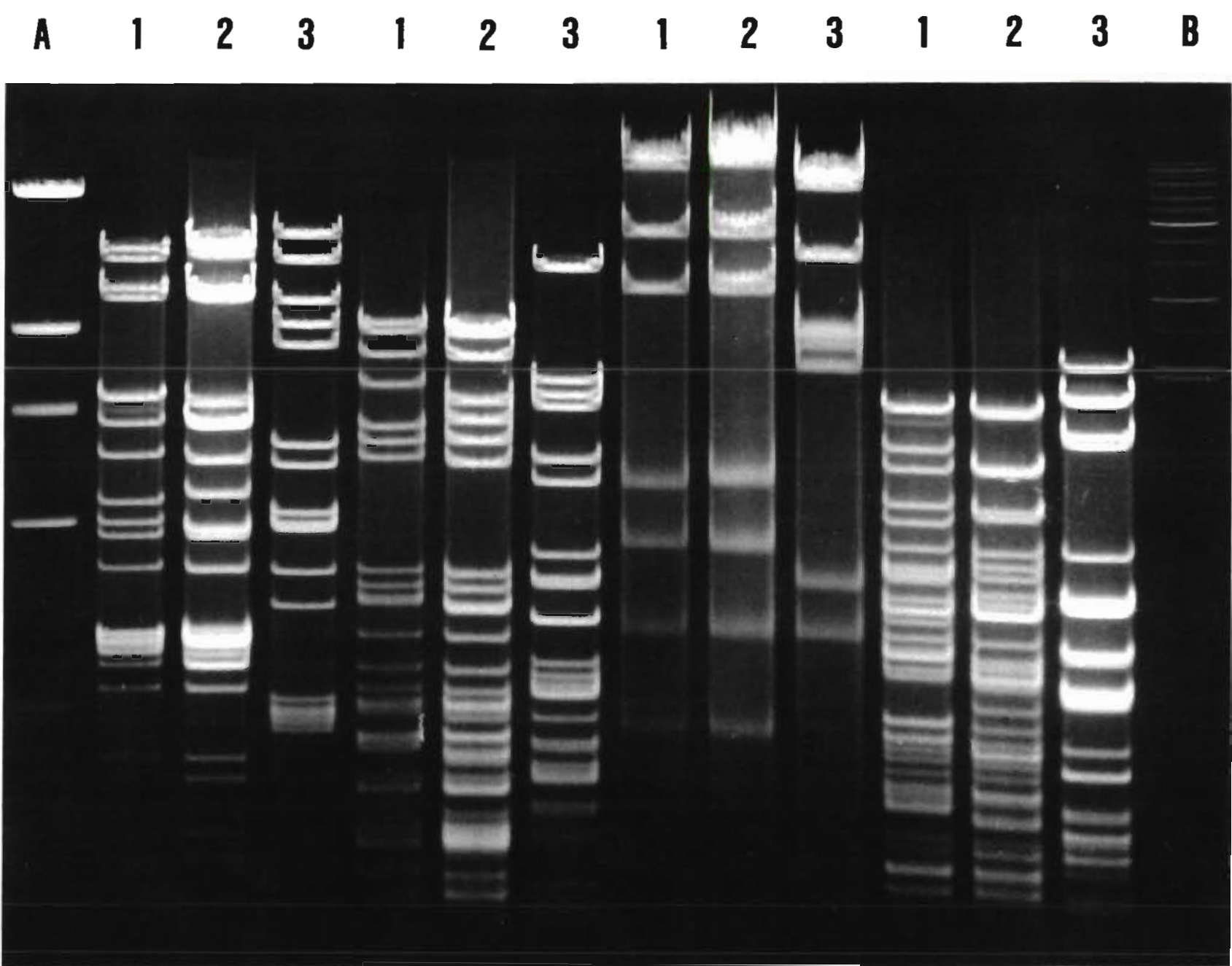

Fig. 9. Restriction endonuclease digestion patterns for the DNA from (1) EHNV ${ }_{R F}$, (2) EHNV $\mathrm{E}_{\mathrm{T}}$ and (3) BIV digested with KpnI, BamHI, HindIII or Ncol. Markers were (A) $\lambda$ DNA digested with Hindlll $(23.1,9.42,6.68,4.36,2.32$ and $2.03 \mathrm{~kb}$ ); and (B) $\lambda$ highmolecular-weight markers $(48.5,38.4,33.5 .29 .9,24.8,22.6,19.4,17.1,15.0,12.2,10.1,8.6$ and $8.3 \mathrm{~kb})$

Xbal, Bg1ll and PstI (data not shown). Differences, however, between EHNV isolates were relatively minor. With KpnI, Bam HI and NCol, most bands were common to both $\mathrm{EHNV}_{\mathrm{T}}$ and $\mathrm{EHNV}_{\mathrm{RF}}$ DNA, however, some bands were present in only one of the EHNV isolates. Hind III fragment sizes were indistinguishable between EHNV isolates by conventional (Fig. 8) and field inversion gel electrophoresis (data not shown).

Estimates of genome size by addition of restriction fragment sizes (using enzymes KpnI, XbaI, BamHI, BgllI, NCoI and HindIII) indicated that the 2 isolates of EHNV had DNAs that were $125 \pm 10 \mathrm{~kb}$ and that of BIV was $109 \pm 12 \mathrm{~kb}$.

A cross-hybridization experiment using approximately equal concentrations of DNA from all 3 iridovirus isolates with vaccinia virus and calf thymus DNA as controls indicated a high level of sequence homology between the 3 iridoviruses (Fig. 10). No cross reactions with either vaccinia virus or calf thymus DNA were observed. The high stringency conditions used to wash the blots suggested a level of homology in the order of $90 \%$. In each case a slightly higher level of hybridization, indicated by the intensity of the spots, was achieved with the homologous probe. 
Fig. 10. Five-fold dilutions of DNA (initial amount added $0.5 \mu \mathrm{g}$ ) from EHNV $_{R T}, E_{T N} V_{T}, B I V$, vaccinia virus and calf thymus were hybridized with ${ }^{32}$ P-labeled DNA from either EHNV $V_{R T}$ or BIV. Unbound probe was washed off with $0.1 \times \mathrm{SSC} / 0.1 \%$ $\operatorname{SDS}$ at $60^{\circ} \mathrm{C}$
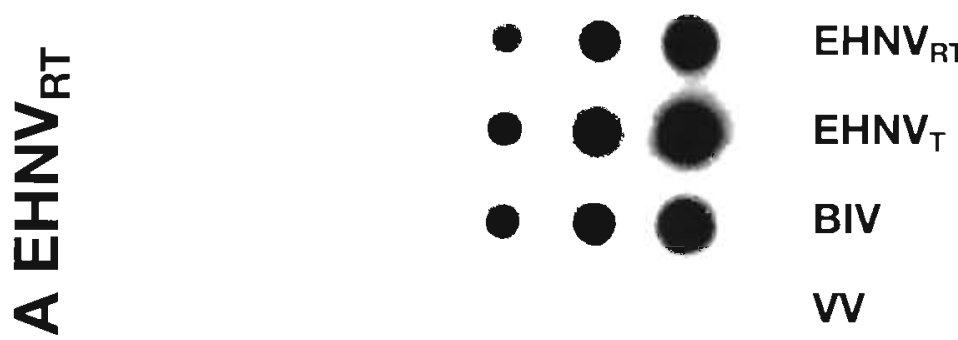

calf thymus

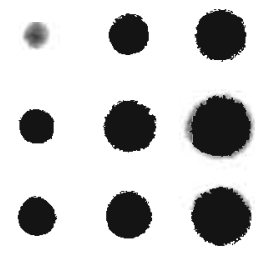

EHNV $_{\text {RT }}$

$\mathrm{EHNV}_{\mathrm{T}}$

BIV

W

\section{calf thymus}

\section{DISCUSSION}

Although the overall ultrastructural and morphogenic events appeared to be very similar for both BIV and EHNV, the viruses differed in both size and the site of virus release from host cells.

EHNV has been reported (Eaton et al. 1991) to bud from the host cell plasma membrane. Data from this study indicated that EHNV was similar to FV3 (Tripier et al. 1974, Murti et al. 1985a) in that it buds from both the elongated cellular processes which are rich in microfilaments (Murti et al. 1985b) and from thickened areas of cell membrane associated with the body of the cell. Cells infected with BIV, however, did not produce long cellular protrusions. The significance of this difference is not known.

BIV was also found to be significantly smaller $(159 \mathrm{~nm})$ than EHNV $(172 \mathrm{~nm})$. The size, measured vertex to vertex, was intermediate between that reported for non-enveloped FV3 (145 nm) (Lunger \& Came 1966, Tripier \& Kirn 1973) and EHNV under the same conditions (i.e. vertex to vertex in thin sections). The icosahedral capsid of FV 3 consists of 72 to $75 \AA$ capsomers which contain a trimeric arrangement of a $49 \mathrm{kD}$ protein (Darcy-Tripier et al. 1986). The analogous protein in EHNV had a MW of $51 \mathrm{kD}$. Eaton et al. (1991) found that this polypeptide, which is slightly larger than the cognate protein in FV3, constituted 75 to $90 \AA$ capsomers which were themselves larger than those of FV3. The data suggested that BIV contained a $49 \mathrm{kD}$ capsid protein which was antigenically related to that of EHNV. Although the capsomeric subunits of BIV were not isolated and measured in this study, it would appear that the difference in size between EHNV and BIV capsids could be the consequence of capsomeric proteins of different molecular weights.

Differences between the piscine and amphibian isolates become more pronounced at the protein level The polypeptide profiles for the piscine isolates were very similar. To date only $1 \mathrm{EHNV}_{\mathrm{RF}}$ and $\mathrm{EHNV}_{\mathrm{T}}$ isolate have been examined and the minor differences which exist must therefore be viewed with caution. Although differences between the piscine and amphibian viruses were more pronounced, the data indicated that EHNV and BIV proteins exhibited varying degrees of antigenic cross-reactivity. In FV $3,48,44,43$, and $38 \mathrm{kD}$ proteins have been reported to be associated with the virion surface (Chinchar et al. 1984, Darcy-Tripier et al. 1986). Proteins of similar size were found in EHNV and BIV and reacted with EHNVspecific antiserum in Western blots. The presence of 
antigenically related proteins in EHNV and BIV explains the cross-reactivity displayed by specific antisera in IEM and antigen capture ELISAs. The possession of similar antigenic epitopes in piscine and amphibian iridoviruses also indicates the necessity of developing further diagnostic tests to replace those currently available (Hyatt et al. 1991. Steiner et al. 1991). Such diagnostic assays utilise polyclonal antisera identical to those described in this paper and are therefore not appropriate for the specific detection of EHNV. The results in this report, however, indicate that it is possible to differentiate between $E H N V_{T}$, EHNV $_{R F}$ and BIV by the use of Western blots. The specific labelling of 38 and $45 \mathrm{kD}$ proteins by anti$\mathrm{EHNV}_{\mathrm{T}}$ antiserum would be sufficient to discriminate the isoldies.

Although the origin of Australian iridoviruses is unknown, EHNV and BIV appear to be related. Comparison of polypeptides from BIV with those of FV3, as described by Willis et al. (1977) and Elliot \& Kelly (1980), indicate that FV3 has many proteins of similar MW (e.g. 98, 93, 69, 61, 52, 50, 46, 44, 36, 31, 29 and $27 \mathrm{kD}$ ). The similarity of BIV to FV3 was also evident by comparing the restriction endonuclease (KpnI and HindIII) profiles with those of FV3 (Essani \& Granoff $1989)$ and the susceptibilty of FV3 and BIV to different restriction enzymes. Both EHNV isolates and BIV were susceptible to digestion with Xbal. Other ranaviruses such as tadpole edema virus (TEV) and Lucke triturus virus (LTV) are also digested with this restriction enzyme but GFV is not (Essani \& Granoff 1989). These ranaviruses have been described to be closely related with homologies of $90 \%$ or greater, however only $24 \%$ homology was observed between FV3 and GFV (Essani \& Granoff 1989). Results from this paper showed that the Australian iridoviruses were closely related with homologies of ca $90 \%$. The ability of restriction enzymes to detect differences between the genomic DNAs of the Australian isolates suggested that the piscine and amphibian isolates represent different strains of the same genus which is probably the Ranavirus genus. Data from Hedrick et al. (1992), which was published during the preparation of this manuscript, showed that there was a striking similarity between EHNV and the iridoviruses from the sheatfish Silurus glanis which was isolated in northwestern Germany (Ahne et al. 1989) and the catfish Ictalurus melas (Pozet et al. 1992) which was isolated in France and FV3. Collectively these data suggest that all these viruses should be grouped into the same genus, namely, the genus Ranavirus. Due to the geographical isolation of Australia, hybridization studies involving specific Australian aquatic iridoviruses and exotic viruses such as FV3 and GFV cannot be performed until virus isolates and/or DNA can be obtained from North America or Europe. At present we are trying to acquire antisera and cloned DNA of the exotic viruses for future comparative studies.

As EHNV and BIV appear to be different strains of the same group of iridoviruses, it is interesting to note that EHNV has been transmitted, under laboratory conditions, to 7 other endemic and indigenous fish species (Langdon 1989). These included mosquito fish Gambusia affinis (Baird \& Girard), mountain galaxias Galaxias olidus (Gunther), Macquarie perch Macquaria australasica (Cuvier), silver perch Bidyanus bidyanus (Mitchell), Murray cod Maccullochella peeli (Mitchell) and golden perch Macquaria ambigua (Richardson). Of these species, mosquito fish, silver perch, Murray cod and goiden perch share a common geographical distribution along the eastern coast of Australia. Despite the geographical distribution of susceptible species, EHNV has, to date, been detected only in Victoria, southeast New South Wales and South Australia, and BIV only in Queensland. The isolations have, in the main, been from samples submitted for diagnosis and not from extensive national field surveys. The overall distribution of both isolates throughout the Australian continent is therefore largely unknown. The results presented in this report therefore raise many environmental questions. For example, what are the overall distributions of EHNV and BIV? Has BIV been transmitted (in the field) to Bufo marinus (cane toads) which are currently advancing across the Australian continent? Can BIV infect fish and EHNV infect frogs? Can frogs and cane toads survive infection and become carriers? If the distributions of these viruses are not ubiquitous and the answer to any of the preceding questions is yes, then what will be the environmental impact on Australia's indigenous piscine and amphibian fauna?

Acknowledgements. The authors express their appreciation for the interest shown by the late Dr Jeremy Langdon in studies on EHNV and related viruses. His knowledge, enthusiasm and involvement in the study of fish diseases will be sadly missed.

\section{LITERATURE CITED}

Ahne, W., Schlotfelt, H. J., Thomsen, I. (1989). Fish viruses isolation of an icosahedral cytoplasmic deoxyribvirus from sheatfish (Silurus glanis). J. vet. Med. 36: 333-336

Chinchar, V. G, Metzger, D. W., Granoff, A., Goorha, R (1984). Localization of Frog virus 3 proteins using monoclonal antibodies. Virology 137: 211-216

Coupar, B. E. H., Teo, T., Boyle, D. B. (1990). Restriction endonuclease mapping of the fowlpox virus genome Virology 179: 159-167

Darcy-Tripier, F., Nermut, M. V., Brown, E., Nonnenmacher H., Braunwald, J. (1986). Ultrastructural and biochemical 
evidence of the trimeric nature of frog virus 3 (FV3) sixcoordinated capsomers. Virology 149: 44-54

Eaton, B. T., Hyatt, A. D., Hengstberger, S. M. (1991) Epizootic haematopoietic necrosis virus: purification and classification. J. Fish Dis. 14: 157-169

Elliot, R. M. Kelly, D. C. (1980). Frog virus 3 replicationinduction and intracellular distribution of polypeptides in infected cells. J. gen. Virol. 37: 28-51

Essani, K., Granoff, A. (1989). Amphibian and piscine iridoviruses proposal for nomenclature and taxonomy based on molecular and biological properties. Intervirology 30 : $187-193$

Francki, R. I. B., Fauquet, C. M., Knudson, D. L., Brown, F (1991). Classification and nomenclature of viruses. Arch Virol. (suppl.) 2: 132-136

Hedrick, R. P., McDowell, T S., Ahne, W., Torhy, C., de Kinkelin, P. (1992). Properties of the three iridovirus-like agents associated with systemic infections of fish. Dis. aquat. Org. 13: 203-209

Hyatt, A. D., Eaton, B. T., Hengstberger, S. M., Russell, G. (1991). Epizootic haematopoietic necrosis virus: detection by ELISA, immunohistochemistry and immunoelectronmicroscopy. J. Fish Dis. 14(6): 605-617

Hyatt, A. D., Eaton, B. T., Lunt, R. (1987). The grid-cell-culture technique: the direct examination of virus-infected cells and progeny viruses. J. Microscopy 145: 97-106

Laemmli, U. K. (1970). Cleavage of structural proteins during the assembly of the head of bacteriophage T4. Nature 227: $680-685$

Langdon, J. S. (1989). Experimental transmission and pathogenicity of epizootic haematopoietic necrosis virus (EHNV) in redfin perch, Perca fluviatilis L., and 11 other teleosts. J. Fish Dis. 12: 295-310

Langdon, J. S., Humphrey, J. D., Williams, L. M. (1988). Outbreaks of an EHNV-like iridovirus in cultured rainbow

Responsible Subject Editor: F. M. Hetrick, College Park, Maryland, USA trout, Salmo gairdneri Richardson, in Australia. J. Fish Dis 11: $93-96$

Langdon, J. S., Humphery, J. D., Williams, L. M., Hyatt, A. D. Westbury, H. A. (1986). First virus isolation from Australian fish: an iridovirus-like pathogen from redfin perch, Perca fluviatilis L. J. Fish Dis. 9: 263-268

Lunger, P. D., Came, P. E. (1966). Cytoplasmic viruses associated with Lucke' tumour cells. Virology 30: 116-126

Murti, K. G., Chen, M., Goorha, R. (1985a). Interaction of Frog Virus 3 with the cytomatrix: III. Role of microfilaments in virus release. Virology 142: 317-325

Murti, K. G., Goohra, R., Chen, M. (1985b). Interaction of Frog virus 3 with the cytoskeleton. Curr. Topics Microbiol. Immunol. 116: 107-131

Pozet, F., Moussa, A., Torhy, C., de Kinkelin, P. (1992). Isolation and preliminary characterisation of a pathogenic icosahedral deoxyribovirus from the catfish Ictalurus melas. Dis. aquat. Org. 14:35-42

Speare, R., Smith, J. R. (1992). An iridovirus-like agent isolated from the ornate burrowing frog Limnodynastes ornatus in northern Australia. Dis. aquat. Org. 14: 51-57

Steiner, K. A., Whittington, R. K., Petersen, R. K., Hornitzky, C., Garnett, H. (1991). Purification of epizootic haematopoietic necrosis virus and its detection using ELISA J. virol. Meth. 33: 199-209

Tripier, F., Braunwald, J., Markovic, L., Kirn, A. (1974). Budding of frog virus 3 studied by immunological and cytochemical methods in electron microscopy. Intervirology $3: 305-318$

Tripier, F., Kirn, A. (1973). Mise en evidence de l'ultrastructure du FV3 (frog virus 3). Annls Microbiol. 124A: 155-168

Willis, D. B., Goorha, R., Miles, M., Granoff, A. (1977). Macromolecular synthesis in cells infected by frog virus 3 . VII. Transcriptional and post-transcriptional regulation of virus gene expression. J. Virol. 24: 326-342

Manuscript first received: September 15, 1992

Revised version accepted: November 17, 1992 